\title{
Foucault, Neoliberalism, and Equality
}

\author{
Tuomo Tiisala
}

The charge is familiar by now. Michel Foucault's uncritical engagement with neoliberalism, revealed by his posthumously published 1979 lecture course, shows not only that Foucault is an inept ally for progressive politics today but also confirms the suspicion that a strategic allegiance lay hidden between his work and the agenda of neoliberalism. ${ }^{1}$ As readers of the lectures know, however, the notion of neoliberalism is complicated. Foucault's analysis highlights the decisive theoretical and political differences between American neoliberalism developed by the Chicago School on the one hand and the German neoliberalism of the Ordoliberals on the other, which respectively constitute two distinct paths of "programming anew the liberal rationality of governing [la gouvernementalité libérale]" in the twentieth century. ${ }^{2}$ The latter, which continues to define the policy playbook of the European Union, for instance, embeds the economic market in a framework of political institutions, including a commitment to substantial welfare policies, all understood as necessary social preconditions for a well-functioning market. What the critics of Foucault have in mind, of course, is American neoliberalism, which, in contrast, defines rational agency in terms of market

I am grateful to Bernard Harcourt, Thimo Heisenberg, Magdalena Małecka, Jake McNulty, Timo Miettinen, and Richard Neer for comments on drafts of this article. I also wish to thank the audiences who attended my talks on this topic at Copenhagen Business School, The New School for Social Research, and the University of Helsinki, as well as the organizers of these events, especially Morten Sørensen Thaning and Daniel Rodriguez-Navas. Unless otherwise noted, all translations are my own.

1. For the provocative tone behind the controversy, see Daniel Zamora, "Introduction: Foucault, the Left, and the 1980s," in Foucault and Neoliberalism, ed. Zamora and Michael C. Behrent (Malden, Mass., 2015), pp. 10-13.

2. Michel Foucault, Naissance de la biopolitique: Cours au Collège de France 1978-1979 (Paris, 2004), p. 95; hereafter abbreviated $N$. 
relations and seeks to transform, theoretically and politically, all social relations into market relations. Therefore, my focus, too, will be on this more radical type of neoliberalism. Already in 1979 Foucault registers its "differently rigorous or differently complete and exhaustive radicality," before Ronald Reagan and Margaret Thatcher channeled neoliberalism politically as the rationality that came to dominate governing through the next decades till our present $\left(N\right.$, p. 248). ${ }^{3}$ Concurrently with this ascendance of neoliberalism, economic inequality in the US has regressed to the extravagant levels of the 1920s. Yet it should not be surprising, so the charge goes, if Foucault's work appears sterile in the face of these developments. Foucault's lectures on American neoliberalism reveal that this critical impotence is no accident. For in his analysis of the work of Gary Becker, a key figure of the Chicago School, Foucault welcomes and endorses the neoliberal rationality. ${ }^{4}$ No doubt, many of Foucault's followers are struggling in denial or trying to reorient themselves because we now know that the erstwhile critic par excellence in fact ushered in the world of injustice true progressives need to denounce today.

While I, like most readers of Foucault, do not endorse this narrative, I believe the ongoing controversy merits close attention for several reasons. Foucault's sympathizers have typically failed to admit that he does in fact

3. Following Foucault, I am using the term governing in the broad sense of a conduction of conduct. Autonomy, too, is a species of governing, namely self-governing, but I will discuss governing in this article only from the perspective of rationalities through which some conduct the conduct of others. Thus understood, a rationality of governing is a practice of thinking that defines why and how some undertake to conduct the conduct of others. See Foucault, "The Subject and Power," in Power, vol. 3 of Essential Works of Foucault 1954-1988, trans. Robert Hurley, ed. James D. Faubion (New York, 2001); hereafter abbreviated "S." (This text was originally published, and probably also written, in English.) For the related notion of rationality, see Foucault, "Table ronde du 20 mai 1978," in Dits et écrits, 1976-1988, ed. Daniel Defert, François Ewald, and Jacques Lagrange, 2 vols. (Paris, 2001), 2:844-49.

4. In his 1979 lecture course, Foucault cites three texts by Becker: see Gary Becker, "Investment in Human Capital: A Theoretical Analysis," Journal of Political Economy 70 (Oct. 1962): 9-49, "Crime and Punishment: An Economic Approach," Journal of Political Economy 76 (Mar.-Apr. 1968): 196-217, and The Economic Approach to Human Behavior (Chicago, 1976). I do not try to assess how accurately Foucault interprets Becker's views. For Becker's generally favorable commentary on Foucault's interpretation of his work, see Becker, Ewald, and Bernard Harcourt, "Becker on Ewald on Foucault on Becker: American Neoliberalism and Michel Foucault's 1979 'Birth of Biopolitics' Lectures," The Carceral Notebooks 7 (2011): 1-35 and "Becker and Foucault on Crime and Punishment," The Carceral Notebooks 9 (2013): 5-45. These are transcriptions of two public conversations between Harcourt, Becker, and Ewald at the University of Chicago on 9 May 2012 and 15 May 2013, respectively.

Tuomo Tirsala is a university lecturer in practical philosophy at the University of Helsinki. 
welcome and even endorse aspects of Becker's neoliberal theory. ${ }^{5}$ Therefore, a successful interpretation of Foucault's relationship with neoliberalism needs to acknowledge this salutary response and explain it in terms that disentangle Foucault's motives from a blanket ascription of neoliberal commitments. My first goal in this article is to offer such a nuanced reading. The key is to link Foucault's discussion of Becker with the main argument of Discipline and Punish, where Foucault shows how the rationality of penal practices was transformed and geared towards a new goal of normalization during the first half of the nineteenth century. But Becker's account of crime and punishment, an application of his neoliberal theory of rational agency to a specific domain of action, reconfigures penal rationality in terms that undermine the project of normalization. Given Foucault's aim to overcome the apparatus of normalization, this feature of Becker's work indeed merits a sympathetic response. But we will see that it can be separated, as Foucault does, from any broader endorsement of Becker's neoliberal economic theory or its political implications.

However, I do believe that there is a strategic allegiance between Foucault's work and today's neoliberal governmental rationality, even though the connection has nothing to do with Foucault's 1979 lectures. My second goal is to explain this strategic link in terms of an analytic of power that employs Foucault's methodological ideas to study the power effects his own work has created in the posthumous context marked by the ascendance of neoliberalism. By thus analyzing Foucault's work "on the level of its existence," as a discursive practice that is causally linked to other social practices in a particular historical context, it becomes possible to explain its strategic allegiance with neoliberal governmental rationality, while denying any logical or conceptual link between the two. ${ }^{6}$ I will argue that Foucault's remarkable success in drawing attention to the political stakes of subjectivity has posthumously come to reinforce the neoliberal exclusion of economic equality as a topic of political discourse. To specify the nature of this link I will introduce the concept of topical exclusion. It enables one to incorporate the social production of ignorance into an analytic of power but, crucially, without harking back to the notion of false consciousness. Topical exclusion takes place on the level of attention. A topic of general interest such as economic equality may become marginalized, even excluded, from political discourse

5. See Becker, Ewald, and Harcourt, "Becker on Ewald on Foucault on Becker" and "Becker and Foucault on Crime and Punishment."

6. Foucault, "Foucault explique son dernier livre," in Dits et écrits, 1:806. See also Foucault, "Réponse à une question," in Dits et écrits, 1:708 and "La philosophie analytique de la politique," in Dits et écrits, 1976-1988, 2:540. 
because the focus of political attention, and consequently also the understanding of what politics is about, has shifted elsewhere-for instance, from economic equality to questions of identity. Whereas the neoliberal governmental rationality conceptually eliminates economic equality as a topic of justice, Foucault's work has posthumously come to function as an unwitting ally that reinforces this topical exclusion. This, I will argue, is a central yet unintended effect of Foucault's success in drawing attention to the political stakes of subjectivity.

In the end, by introducing the concept of topical exclusion, my aim is to make a contribution whose importance extends beyond the controversy at hand. The strategic link I identify between Foucault's work and neoliberalism underscores the urgent need to theorize how the management of attention functions in tactics and strategies of power today. This is an essential task for any adequate analysis of how power is exercised in a world of digital platforms that nudge us with endless algorithmic resources. ${ }^{7}$ Yet the phenomenon of topical exclusion risks being theoretically occluded by the power/knowledge interface Foucault was so keen to study. In History of Sexuality, for instance, Foucault undertakes to explain the emergence of sexuality as a field of scientific study in terms of "the strategies of power that are immanent to this will to know" and identifies, to that end, "four main strategies deployed in the nineteenth century: sexualization of the child, hysterization of the woman, specification of the perverts, regulation of populations." "In Foucault's analysis, these strategies of power support the will to seek knowledge about sexuality and rely on the resultant discursive practice in their own expansion. Indeed, Foucault underscores, it is a question of power that cannot be exercised without a sustained will to know, which manifests as a continuous production of truth-claims about its objects. ${ }^{9}$

7. For some of the most illuminating work on this new constellation of power, see Tamsin Shaw, "Invisible Manipulators of Your Mind," review of The Undoing Project: A Friendship That Changed Our Minds by Michael Lewis, The New York Review of Books, 20 Apr. 2017, www .nybooks.com/articles/2017/04/20/kahneman-tversky-invisible-mind-manipulators; Shoshana Zuboff, The Age of Surveillance Capitalism: The Fight for a Humane Future at the New Frontier of Power (New York, 2019); and Colin Koopman, How We Became Our Data: A Genealogy of the Informational Person (Chicago, 2019).

8. Foucault, La volonté de savoir, vol. 1 of Histoire de la sexualité (Paris, 1976), pp. 98, 150.

9. See Foucault, "Il faut défendre la société": Cours au Collège de France 1975-1976 (Paris, 1997), p. 22. With the benefit of hindsight, Foucault came to distinguish three levels of organization for relations of power, understood as actions on the actions of others: (1) relations of force between individuals, (2) governmental rationalities, and (3) states of domination. I believe that the claim that power cannot be exercised without reliance on a discursive practice of truth-claims should be restricted to the level of governmental rationality, which is where Foucault locates the power/knowledge interface. See Foucault, "L'éthique du souci de soi comme pratique de la liberté," in Dits et écrits, 2:1547. 
Therefore, it is my ultimate aim in this article to introduce topical exclusion as a conceptual supplement that enables one to explain how, in other cases, tactics and strategies of power harness and produce ignorance instead. The concept brings into relief the need for a political economy of attention in the analysis of how power is exercised.

\section{Foucault's Genealogy of Modern Governmental Rationality}

Foucault's surprising engagement with neoliberalism needs to be contextualized in his genealogy of modern governmental rationality. While Foucault's analyses range from the emergence of pastoral power in early Christianity through nineteenth-century forensic psychiatry to French court cases in the 1970s, they are unified by the aim to explain how governmental rationality became organized around the goal of normalization. This explanatory task is subservient to Foucault's ultimate aim to enable, even catalyze, a transformation of the given governmental rationality. The historical work aims to promote autonomy in the present by making the rationality of normalization intelligible as a contingent configuration that can be resisted and overcome. Thus, by explaining how the rationality of governing became organized in terms of normalization, Foucault seeks to destabilize the given apparatus of normalization that spans the fields of penality, sexuality, and beyond. ${ }^{10}$ Understanding how the apparatus of normalization took shape in history is meant to empower people in the present to create a world without it. ${ }^{11}$

This focus on normalization is motivated by Foucault's overarching project to investigate "the relations between the subject and truth." ${ }^{12}$ In 1978, a year before the lectures on neoliberalism, Foucault notes that an analytic of power, specifically an analysis of governmental rationality, is needed to understand the relationship between truth and subjectivity: "my problem is to know how people govern (themselves and others) through the production of truth (I repeat it again, by the production of truth I don't mean the production of true statements but the configuration of fields where the practice

10. See Foucault, "Entretien de Michel Foucault avec André Berten, 7 mai 1981," in Mal faire, dire vrai: Fonction de l'aveu en justice. Cours de Louvain, 1981, ed. Fabienne Brion and Harcourt (Louvain-la-Neuve, 2012), pp. 242-43. See also Foucault, "Est-il donc important de penser?" in Dits et écrits, 2:999-1000 and "Structuralisme et poststructuralisme," in Dits et écrits, 2:1267-68, and Friedrich Nietzsche, "On the Uses and Disadvantages of History for Life," in Untimely Meditations, trans. R. J. Hollingdale, ed. Daniel Breazeale (Cambridge, Mass., 1997), pp. 75-77.

11. For a discussion of genealogy's explanatory role in the promotion of freedom, see Michael Forster, "Genealogy," American Dialectic 1, no. 2 (2011): 230-50, and Colin Koopman, Genealogy as Critique: Foucault and the Problems of Modernity (Bloomington, Ind., 2013). See also John Richardson, Nietzsche's Values (New York, 2020), pp. 322-27.

12. Foucault, "L'éthique du souci de soi comme pratique de la liberté," p. 1536. 
of the true and the false can be at the same time rule-governed [réglée] and relevant)." ${ }^{13}$ The link between the subject and truth is not merely epistemic, but, by the same token, it constitutes individuals as subjects to be governed according to some specific rationality. For example, the constitution of the delinquent and the pervert as objects of nineteenth-century human sciences is inseparable from the emergence of the new rationality of governing people with the goal of normalization. Not only does it apply to those who have been classified as different kinds of abnormal individuals but also to those, in effect everyone, who might be abnormal. ${ }^{14}$ This rationality of governing makes every individual obligated to seek the truth about one's normality and to correct potential deviations from the norm. Thus, the link between the subject and truth is embedded in a particular governmental rationality in which it plays the pivotal role of defining who is to be governed, by whom, how, and why. For instance, Foucault shows how sexual conduct was incorporated into the apparatus of normalization once people, the entire population of individuals, became constituted as objects of a psychiatric discourse of sexuality. ${ }^{15}$

A governmental rationality always rests on some set of truth-claims, but a key event in Foucault's genealogy occurs when the source of these truthclaims becomes located in the discursive practices of human sciences. In this shift, a new basis for rationalizing governing takes shape, one that is independent of legal, moral, and religious authority precisely because it consists of scientific truth-claims about the normal and the pathological: "We have entered into a type of society where the power of law is not decreasing but being integrated with a power that is much more general, broadly speaking, the power of the norm." ${ }^{16}$ Nor is it just any social norms but specifically standards of normality articulated by human sciences that establish a new basis for governmental rationality: "The preponderance conferred onto pathology becomes a general form of governing society [une form générale de régulation de la société]. Today medicine no longer has a field outside of itself." ${ }^{17}$ Finding its basis in the discursive practices of human sciences, the rationality of normalization emerges, expands, and begins to function as an apparatus that brings together previously distinct social practices: "Medical

13. Foucault, “Table ronde du 20 mai 1978 ," p. 846.

14. Studying the conceptual preconditions for introducing normalization to the field of sexuality, Arnold Davidson sums up how the concept of sexual perversion affects everyone, thus: "our existence became a sexistence, saturated with the promises and threats of sexuality" (Arnold I. Davidson, The Emergence of Sexuality: Historical Epistemology and the Formation of Concepts [Cambridge, Mass., 2001], p. xiii).

15. See Foucault, La volonté de savoir. See also Davidson, The Emergence of Sexuality.

16. Foucault, "L'extension sociale de la norme," in Dits et écrits, 2:75.

17. Foucault, "Crise de la médecine ou crise de l'antimédecine?" in Dits et écrits, 2:53. 
power is at the heart of the society of normalization. One sees the effects of medicine's power appear everywhere: be it in the family, at school, in the factory, in the courts, concerning sexuality, education, work, crime. Medicine has become a general social function: it invests the law, attaches to it, makes it function." ${ }^{18}$ Foucault's genealogical aim is to reveal that this governmental rationality that is normalizing - and appears to be necessarily so-is, in fact, a "transformable singularity," specifically an apparatus whose rationality has coalesced in history and whose different functions can be decoupled and redefined. ${ }^{19}$ For instance, Foucault's History of Sexuality seeks to enable new forms of subjectivity through which sexual conduct is constituted as an object of self-governing from an ethical perspective, in contrast to the received rationality of governing sexual conduct on the basis of psychiatric truth-claims regarding the normal and the pathological. ${ }^{20}$

No doubt, these are familiar ideas that have been discussed extensively, but I need to invoke them nevertheless as essential background for understanding Foucault's engagement with Becker's neoliberalism. In this respect, it is particularly important to grasp why Foucault focuses on subjectivity, making his critical project "a historical ontology of ourselves." ${ }^{21}$ Foucault's line of work, as I have summarized it, is meant to reinforce ongoing "struggles against the 'government of individualization'" in the fields of mental health, penality, and sexuality, all functioning as parts of the apparatus of normalization ("S," p. 330). Foucault explains that "the main objective of these struggles is to attack not so much such-or-such institution of power, or group, or elite, or class but, rather, a technique, a form of power . . . that categorizes the individual, marks him by his own individuality, attaches him to his own identity, imposes a law of truth on him that he must recognize and others have to recognize in him" ("S," p. 331). If subjectivity plays a crucial role in

18. Foucault, "L'extension sociale de la norme," p. 76.

19. Foucault, "Préface à l'Histoire de la sexualité," in Dits et écrits, 2:1399.

20. Foucault's History of Sexuality aims to destabilize and overcome two interconnected targets at two distinct levels. The most immediate target is the given governmental rationality that defines sexuality in terms of the normal and the pathological, based on truth-claims of a scientific discourse. This governmental rationality relies on a regime of truth, in which every individual has an obligation to seek the truth about oneself through an interpretation of one's sexual desire. As Foucault's genealogy reveals, this obligation extends back to early Christianity, whereas its coalescence with normalization is a distinctively modern development. Ultimately, Foucault's target is that underlying obligation to constitute oneself as a subject through an interpretation of one's sexual desire. See Davidson, "La fin de l'herméneutique de soi," in Michel Foucault: éthique et vérité, ed. Ariane Revel, Daniele Lorenzini, and Arianna Sforzini (Paris, 2013), pp. 67-76. For a discussion of Foucault's alternative vision, see David Halperin, "The Queer Politics of Michel Foucault," Saint Foucault: Towards a Gay Hagiography (New York, 1995), pp. 15-125.

21. Foucault, "Qu'est-ce que les Lumières?" in Dits et écrits, 2:1393; hereafter abbreviated "Q." 
resisting and reconfiguring the apparatus of normalization, it is because its governmental rationality relies on a specific understanding of individuals in terms of the normal and the pathological. Therefore, Foucault emphasizes that this governmental rationality can be permanently disrupted only by undoing the form of subjectivity that makes it function. ${ }^{22}$ That is why Foucault urges, highlighting the political dimension of "a historical ontology of ourselves," that people repudiate the identities that descend from the apparatus of normalization (“Q," p. 1393):

Maybe the most certain of all philosophical problems is the problem of the present time, and of what we are, in this very moment.

Maybe the target nowadays is not to discover what we are but to refuse what we are. We have to imagine and build up what we could be to get rid of this kind of political 'double bind,' which is the simultaneous individualization and totalization of modern power structures.

The conclusion would be that the political, ethical, social, philosophical problem of our days is not to try to liberate the individual from the state, and from the state's institutions, but to liberate us both from the state and from the type of individualization linked to the state. We have to promote new forms of subjectivity through the refusal of this kind of individuality that has been imposed on us for several centuries. [“S,” p. 336; my emphasis]

From the perspective of Foucault's concern with normalization, then, Becker's work obtains its significance as signaling a departure from the governmental rationality that aims at normalization. As we will see, the conceptual structure of Becker's theory of homo economicus does away with individualization that subjects individuals to the apparatus of normalization. Therefore, from Foucault's critical perspective towards normalization, Becker's theory constitutes not merely a conceptual alternative but a political improvement. This does not mean that a governmental rationality based on Becker's theory of homo economicus could not give rise to new problems that are no less severe than normalization yet decidedly different. Before explaining how Becker's theory articulates a governmental rationality without individualization, however, let me contextualize Foucault's discussions of liberalism and neoliberalism in the context of the genealogy whose contours I have sketched.

22. For Foucault's explicit refusal of the idea that one defines one's identity in terms of sexuality, see Foucault, "Entretien de Michel Foucault avec Jean François et John De Wit, 22 mai 1981," in Mal faire, dire vrai, p. 254. Foucault's related notion of totalization also merits a detailed discussion, but I have to postpone it for another occasion. 


\section{Liberalism and Neoliberalism in Foucault's Genealogy}

Foucault begins his 1979 course, The Birth of Biopolitics, by arguing that the apparatus of normalization is genealogically dependent on the political success of laissez-faire liberalism in the second half of the eighteenth century. The liberal economists forged the link that grounds governmental rationality in scientific truth-claims when they succeeded in persuading the state to abstain from market intervention by arguing that the market is naturally set to produce an optimal outcome. Foucault does not attribute epistemic success to this idea, but he studies its political adoption as a historical event. His genealogical argument is that, once the link is established between governmental rationality and truth-claims that carry scientific authority, this link defines a new, decidedly modern way to organize the rationality of governing. Political and legal discourses become subordinated to scientific discourse as the ultimate source of justification and conceptualization. Because this configuration also underlies the apparatus of normalization as we have seen already, it functions as an enabling condition for the birth of biopolitics.

However, it is rather misleading from Foucault to claim that in this shift governmental rationality becomes dependent on "the question of truth" $(N$, p. 24). In his previous lecture course, Foucault had analyzed how the source of the truth-claims that function as the basis of governmental rationality changes from the theology of the Christian pastorate to raison d'état that emerges in the eve of modernity. ${ }^{23}$ What changes is the source of the truth-claims, the type of authority they carry, as well as the socially differentiated obligations to produce truth-claims that enable governing. But it remains constant throughout this long history that the rationality of governing is based on some discursive practice of truth-claims. In fact, the transformations Foucault traces pertain to the regime of truth, a system of social practices that assigns to individuals permissions and obligations to produce truthclaims that are needed for the given governmental rationality. ${ }^{24}$ Therefore, it is not "the question of truth" as such, but specifically the scientific authority of truth-claims, which liberalism introduces as the new basis for organizing the rationality of governing. To appreciate this, it is instructive to ask what exactly Foucault means by "a certain type of discourse," when he describes the key moment liberalism brings about, as follows:

23. See Foucault, Sécurité, térritoire, population: Cours au Collège de France 1977-1978 (Paris, 2004).

24. See Foucault, "Entretien avec Michel Foucault," in Dits et écrits, 2:158-59. It would be illuminating to consider Foucault's notion regime of truth as an elaboration of his earlier discussion of enunciative modalities. See Foucault, L'archéologie du savoir (Paris, 1969), pp. 68-74. See also Lorenzini, La force du vrai: De Foucault à Austin (Lormont, 2017), pp. 41-78. 
It is evidently a key moment because what emerges . . is not, of course, the reign of the true in politics, but a certain regime of truth that characterizes precisely what could be called the age of politics and whose basic apparatus is overall the same still today. When I say regime of truth, I don't mean that politics or the art of governing, if you wish, finally obtains rationality in that epoch. I don't mean that an epistemological threshold is reached such that the art of governing could become scientific on its basis at that moment. What I mean is that at that moment, which I'm currently trying to indicate, a certain type of discourse is articulated to a series of practices - a discourse which, on the one hand, makes the ensemble connected through a link of intelligibility and, on the other, legislates these practices in terms of the true and the false. [N, p. 20; my emphasis]

Here the "type of discourse" is not merely a discourse of truth-claims but such a discourse with a scientific status. This is confirmed by the continuity Foucault quickly notes between the case of liberalism and his other studies: "The goal of all these undertakings with respect to madness, illness, delinquency, sexuality, and what I now talk to you about [liberalism], is to show how the coupling series of practices - regime of truth forms an apparatus of knowledge-power" ( $N$, p. 22; my emphasis). What all these cases have in common is the use of the authority of scientific truth-claims as the basis for organizing the rationality of governing.

After this argument, however, Foucault shifts focus to the twentieth century with the aim of studying how the governmental rationality of laissezfaire liberalism has been reconfigured in German and American neoliberalism, respectively. As I have already indicated, the result is a sharp bifurcation between two types of neoliberal governmental rationality. Foucault's "German neoliberalism" emerges between 1930 and 1950 among a group of German economists who reject the classical view of the market as a system of exchange with a natural equilibrium. They redefine the market as a social institution, always constituted and regulated by a broader institutional framework, whose role is to create and sustain conditions that approximate the ideal of perfect competition. Importantly, this type of neoliberalism understands publicly funded welfare policies and the regulation of markets as two indispensable components of a sound social organization of economic competition. Neoliberalism, thus understood, has been central to the governmental rationality of the European Union since the beginning to this day. In contrast, Foucault's "American neoliberalism," developed by economists at the University of Chicago from the late 1950 s onwards, offers a theory of all social relations as market relations. Its radical divergence from German 
neoliberalism does not escape Foucault: "In the American neoliberalism, it is, in fact, indeed a question of always generalizing the economic form of the market. It is a question of generalizing it all the way to the entire social system that, ordinarily, does not function or is not sanctioned by monetary exchanges" ( $N$, p. 248). Herein, Foucault stresses, lies "the differently rigorous or differently complete and exhaustive radicality" of American neoliberalism vis-à-vis its German counterpart.

Becker's theory of human capital plays a crucial role in making an unconstrained expansion of the market even theoretically palatable. Becker's theory reconceptualizes all social relations, indeed rational action as such, in terms of investment and profit. It thereby profoundly modifies the received conception of rational agency as efficient satisfaction of ranked preferences. In Becker's theory, actions of rational agents are conceptualized as investment decisions that seek profit by means of allocating scarce resources. What matters is the yield, a profit or a loss, that one obtains for the human capital that one invests through action. Every action is an investment decision to expend one's human capital, to allocate resources such as time and skills that can generate a profit. Today we are all familiar with the resultant neoliberal entrepreneurial subject whose posts and likes, as well as the entire digitized social network, function as techniques, assets, and opportunities for generating revenue by developing oneself, according to the logic of invested capital. ${ }^{25}$ In 1979, with no glimpse of the internet, social media, and algorithmic advertising in sight, Foucault nonetheless registers this core rationality of American neoliberalism, though in unavoidably abstract terms, thus:

The homo economicus is an entrepreneur and an entrepreneur of itself. And this is so true that what is at stake, in practice, in all the analyses the neoliberals make, is substituting every time for the homo economicus who is a partner of exchange, a homo economicus that is an entrepreneur of itself, being its own capital, being for itself its own producer, being for itself the source of [its] income. $[N$, p. 232]

This brief summary of the bifurcation of neoliberalism suffices to make it clear that it is specifically American neoliberalism whose governmental rationality poses a threat to a well-functioning democratic society, as Wendy Brown argues, because it only recognizes economic reasons and thereby aims to eliminate moral and political perspectives altogether from the rationality

25. See Harcourt, Exposed: Desire and Disobedience in the Digital Age (Cambridge, Mass., 2015). 
of governing. ${ }^{26}$ Brown's fairly recent diagnosis of this threat may seem to reinforce the charge that Foucault ought to have denounced Becker's ideas and that because he didn't we can rightly hold him accountable for neoliberalism's subsequent theoretical and political victories. There is no doubt that a historical ontology of ourselves, today, requires a genealogy of the neoliberal entrepreneurial subject. But while its rationality permeates our social relations today, in 1979 it must have appeared to Foucault as an abstract, even somewhat fantastical, theoretical construction with no real effects. In fact, the urgency of a critical outlook that is grounded in our own present risks occluding the radically different perspective from which Foucault encounters and evaluates Becker's work. I have already identified the apparatus of normalization as Foucault's guiding concern, so let me next explain how it informs Foucault's sympathetic response to Becker's account of crime and punishment. Because the crucial issue concerns the governmental rationality of penal practices, Foucault's engagement with Becker must be read against the backdrop of the main argument in Discipline and Punish.

\section{Penal Rationality: With and Without Normalization}

If the guiding concern throughout Foucault's genealogy of modern governmental rationality is how governing became normalization, Discipline and Punish examines that question specifically with respect to the rationality of penal practices. ${ }^{27}$ The topic of the book, often overshadowed by the iconic analyses of disciplinary power and the Panopticon, is the formation of a new governmental rationality in the field of penality that is founded on criminological truth-claims about the delinquent as a new object of study. Foucault states this clearly at the outset: "The goal of this book: a correlative history of the modern soul and of a new power to judge; a genealogy of the current scientific-legal complex where the power to judge finds its points of support, receives its justifications and rules, extends its effects, and masks its exorbitant singularity." ${ }^{28}$ In other words, Foucault undertakes to explain how the legal practice of punishing became organized

26. See Wendy Brown, Undoing Demos: Neoliberalism's Stealth Revolution (Brooklyn, N.Y., 2015).

27. Thus, it is instructive to read Discipline and Punish as an actual case study of Nietzsche's rather speculative remarks about how "people think punishment has evolved for the purpose of punishing," but "today it is impossible to say precisely why people are actually punished" because the practice of punishing has served multiple functions in different historical contexts (Nietzsche, On the Genealogy of Morality, trans. Carol Diethe, ed. Keith Ansell-Pearson [New York, 2007], pp. 51, 53).

28. Foucault, Surveiller et punir: Naissance de la prison (Paris, 1975), p. 27; hereafter abbreviated $S$. 
on the basis of scientific truth-claims about the individuals to be punished. Foucault seeks to "understand at the same time how the man, the soul, the individual that is normal or abnormal, have come to double the crime as objects of penal intervention, and in what way a specific mode of subjection could give birth to man as an object of knowledge for a discourse with a 'scientific' status" ( $S$, pp. 28-29). At the heart of this apparatus of knowledge and power we find the delinquent as the new object to be explained and, crucially, normalized:

From the hearing till the sentence and the last stages of the punishment, the penal ritual is thoroughly permeated by a field of objects that come to double, but also to detach the legally defined objects. Psychiatric expertise, but in a more general manner criminal anthropology and the incipient discourse of criminology find there one of their precise functions: in ceremoniously inscribing infractions into the field of objects susceptible to scientific knowledge, giving the mechanisms of legal punishment a justifiable grip no longer merely on the infractions but on the individuals; no longer on what they have done, but on what they are, will be, and can be. [S, pp. 23-24]

This epistemological "doubling" — of the crime by the delinquent, and of the sexual act by the pervert — gives rise to a governmental rationality that targets individuals and aims at their normalization, instead of merely sanctioning forbidden actions. And it is this feature, perhaps so familiar to us that it seems obvious, whose "exorbitant singularity" Foucault's genealogy aims to disclose in order to reinforce the struggle for its dissolution $(S, \mathrm{p} .27)$.

Therefore, it is crucially important that Becker's theory of crime and punishment avoids the pivotal mechanism that subjects people to the apparatus of normalization by means of a "political 'double-bind,' which is the simultaneous individualization and totalization of modern power structures" ("S," p. 336). Becker's approach denies that crime is a manifestation of delinquent personality or of any other psychological characteristic that could be profiled and assessed in terms of the normal and the pathological. By reconceptualizing crime in terms of economic rationality, indeed as an investment that carries a certain level of risk, Becker redefines it as behavior of self-interested agents that respond rationally to the incentive structure of their environment. Foucault underscores the thoroughgoing consequences of this shift, as follows:

This also means that, in this perspective, the criminal is in no way characterized or investigated in terms of moral or anthropological properties. The criminal is nothing other than absolutely anyone. The 
criminal is everyone and thus not treated but as any other person who invests in an action, who expects a profit from it, and who accepts the risk of a loss. From that point of view, the criminal is nothing other and must remain nothing other than that. To that extent, you see that what the penal system is to deal with is no longer this doubled reality of the crime and the criminal. It is conduct, a series of conduct that produces actions. These actions, whose agents expect a profit, are affected by a special risk that is not simply the one of economic loss, but the penal risk or furthermore a risk of this economic loss that is inflicted by a penal system. The penal system itself will not be dealing with criminals, but with people who produce that type of action. To put it differently, it will be reacting to a supply of crime. [N, p. 265; my emphasis]

According to Becker, our rational nature as self-interested economic agents makes us all potential criminals and the political question is how much demand society should create for crime by the incentive structure of its penal code. Thus, Becker's theory redefines crime as just another instance of the general matrix of economic rationality that makes human action governable by incentives. In doing so, Becker's theory redefines the basis of governmental rationality in terms that disable the project of normalization. Therefore, one should not be surprised that Foucault welcomes this shift as an improvement that sketches the contours of a new governmental rationality that will be severed for good from the apparatus of normalization:

It is no longer a society in which the general mechanism of normalization and of the exclusion of the non-normalizable would be required. On the contrary, on the horizon of this, one has the image, the idea, or the platform, of a society in which there would be an optimization of systems of difference, in which there would be tolerance attributed to minority individuals and practices, in which there would be action not on the players of the game but on the rules of the game, and finally in which there would be an intervention that would not be of the type that involves subjection internal to individuals, but a type of intervention that pertains to their environment [il y aurait une intervention qui ne serait pas du type de l'assujetissement interne des individus, mais une intervention de type environnemental]. [N, p. 265; my emphasis]

The crux of the matter is that this shift amounts to "a massive withdrawal in relation to the normalizing-disciplinary system [système normatifdisciplinaire]," whose governmental rationality is based on the individualizing truth-claims of human sciences that make the personality of the individual, under this or that description, the target of control and modification $(N$, 
p. 265). The delinquent and the pervert are individualized as subjects that need to be normalized, whereas the category of the incorrigible, and thus "non-normalizable," captures the "dangerous individual" who needs to be excluded in the interest of social security. ${ }^{29}$ In both cases, the rationality of governing is "internal to individuals" in the sense that it constitutes their subjectivity as a species of the genus abnormal. "This form of power applies itself to immediate everyday life which categorizes the individual, marks him by his own individuality, attaches him to his own identity, imposes a law of truth on him that he must recognize and others have to recognize in him" (“S," p. 331; my emphasis). In Becker's theory, in contrast, Foucault sees an example of an alternative approach that governs people without individualization, namely by using techniques to modify their environment instead. What appeals to Foucault in this alternative is undoubtedly the prospect of governing people without asking who they are and thereby, it seems, giving people autonomy over questions concerning their identity and agency-indeed, as I have emphasized elsewhere, leaving more room for self-governing. ${ }^{30}$

Yet the distinction between interventions that are internal to subjectivity and those that are external, as they modify the environment, threatens to conceal the fact that in both cases a rationality of governing requires subjection [assujetissement] in order to operate. Becker's insight is to turn his account of economic rationality into a theory of rational agency, which offers a general framework for governing people as homo economicus. This framework involves subjection without individualization. Attempts to govern people on the basis of Becker's account of homo economicus must assume that it indeed captures the rationality of human action in the given domain. Foucault, when he discusses Becker's theory, is perfectly aware of this: "what makes the individual governable [gouvernementalisable], what enables getting a hold of the individual, it is to the extent, and only to the extent, that the individual is homo economicus" ( $N$, p. 258; my emphasis). And yet this type of subjection is not individualizing precisely due to its purported generality. In Becker's framework, my being a homo economicus cannot individuate me from others because the economic rationality is what we all share. That is why Becker's neoliberal governmental rationality does not identify different kinds of individuals although its operation, too, relies on a specific form of subjection.

29. Foucault, "L'évolution de la notion d"individu dangereux' dans la psychiatrie légale du XIXe siècle," in Dits et écrits, 2:443-64.

30. See Tuomo Tiisala, "Overcoming 'The Present Limits of the Necessary': Foucault's Conception of a Critique," Southern Journal of Philosophy 55, no. S1 (2017): 14-16. 


\section{Equality}

Even if my interpretation rectifies misunderstandings concerning Foucault's engagement with Becker's ideas, there is another source that fuels speculation about Foucault's neoliberal allegiance. Foucault's work manifests almost complete silence on the topic of justice and, specifically, economic equality. As these topics define the subject matter of political philosophy for many, it is not completely unreasonable to interpret Foucault's silence as evidence of negligence that is analogous to the systematic exclusion of these topics in the neoliberal governmental rationality. The fact that the value guiding Foucault's work is freedom, understood as a historically situated and socially embedded capacity for autonomy, is likely to only reinforce this impression (see "Q"). ${ }^{31}$ Moreover, when Foucault briefly discusses justice, in a debate with Noam Chomsky in 1971, he calls into question the usefulness of the very concept..$^{32}$ Thus, it appears that Foucault's focus on freedom while remaining silent, even skeptical, about justice lines up with the neoliberal elimination of normative questions that are not formulated in terms of economic rationality. However, this interpretation is flawed for two reasons. First, Foucault's sustained focus on the relationship between power and freedom does not preclude a concern for justice, including economic equality, whereas these topics are conceptually eliminated from the neoliberal framework. In fact, as Ben Golder argues, Foucault's political activism, supported by a stream of small publications outside of academic channels, is essential for grasping the tactical use of the concepts of justice and human rights that he came to endorse, in which their justification is detached from any notion of human nature. ${ }^{33}$ Second, it is crucial to appreciate that Foucault's focus on normalization and autonomy is motivated by a concern for equal respect, an essential component of equality that was long eclipsed by questions of distribution in Anglophone political philosophy. Following Elizabeth Anderson's corrective, however, we should acknowledge that equality always concerns relationships between people, as well as patterns of distribution. ${ }^{34}$ Similarly, Charles Mills reminds us that justice is not merely a matter of distributing divisible goods, but it essentially concerns the relations of equal respect between individuals and groups, which are often distorted by entrenched patterns of racist, sexist, and other forms of disrespect. ${ }^{35}$ Adopting the broader conception of equality that Anderson and

31. See Tiisala, "Overcoming 'The Present Limits of the Necessary." "

32. See Foucault, "De la nature humaine: justice contre pouvoir," in Dits et écrits, 1:1368-73.

33. See Ben Golder, Foucault and the Politics of Rights (Stanford, Calif., 2015).

34. See Elizabeth Anderson, "What Is the Point of Equality?" Ethics 109 (Jan. 1999): 287-337.

35. See Charles Mills, "Racial Equality," in The Equal Society: Essays on Equality in Theory and Practice, ed. George Hull (Lanham, Md., 2015), pp. 43-71. 
Mills defend helps one to calibrate also the perspective from which to interpret Foucault's work. From this readjusted angle it is plain to see that Foucault's concern with the status of socially marginalized groups such as mental health patients, prison inmates, and so-called sexual perverts, addresses fundamental problems of equality. Furthermore, Foucault's characteristic refusal to tell people what to think or what to do can be appreciated as a commitment to give equal respect to the autonomy of individuals despite their socially marginalized, even stigmatized, status.

Nevertheless, Foucault remains virtually silent on questions of distributive justice and economic equality. And I do believe that this fact has enabled a strategic allegiance to develop posthumously between Foucault's work and the market fundamentalism of neoliberal governmental rationality. Before explaining what I mean, it is important to note how my diagnosis differs from the vague suggestion that Foucault may "have been seduced" by neoliberalism. ${ }^{36}$ The suggestion is motivated by Foucault's sympathetic response to Becker's work in the 1979 lectures, but I have already explained why and how Foucault's reading of Becker should be interpreted against the backdrop of the apparatus of normalization and specifically in the field of penality alone. And given Foucault's vehement methodological rejection of a theory of human nature, it seems unlikely, to put it mildly, that Becker's theory of homo economicus would have been an exception in this regard. ${ }^{37}$ In contrast, I will defend my alternative diagnosis by explaining a strategic link between Foucault's work and the neoliberal governmental rationality without attributing any neoliberal commitments to Foucault. What matters is not what Foucault said about neoliberalism but his silence on economic equality. Due to that silence, I will argue, Foucault's work has posthumously acquired a role as an unwitting ally of neoliberalism that reinforces its systematic exclusion of the topic of economic equality from political discourse and imagination.

\section{Topical Exclusion}

During the neoliberal period between 1980 and 2020, wealth disparity in the US fell back to its staggering 1920 s levels, and middle-class wages began a steady decline in real terms while the cost of health care and education skyrocketed. Concurrently with this unprecedented regression in economic equality, concerns of disadvantaged minority groups, organized under the umbrella of identity politics, gradually replaced distributive justice and economic

36. Zamora, "Foucault, the Left, and the 1980s," p. 11.

37. See Foucault, "De la nature humaine: justice contre pouvoir," in Dits et écrits, 2:1453. 
equality as the topics defining political discourse and imagination. Needless to say, the struggles of historically oppressed groups for recognition as equals are politically indispensable, and today, in the US of 2021, they are nowhere close to a permanent victory. But the concurrent ascendance of identity politics and the marginalization of economic equality as topics of political attention took place in tandem, as though appreciating one required excluding the other. ${ }^{38}$ Meanwhile, in academic discourse, John Rawls, the preeminent political philosopher of the era, came to reject his original project to develop a theory of distributive justice as "unrealistic" and "impossible." 39 For Rawls, problems of cooperation and stability in a democratic culture of reasonable pluralism replaced justice as the definitive topic of political philosophy. Although Rawls never gave up a theory of justice in his work, its status shifted from the center of political philosophy to the periphery, reflecting a decisive change in ambition and argumentative strategy. In Foucault's work, there is no gradual move away from questions of distributive justice, but its different orientation to begin with, specifically its focus on subjectivity, has come to enable and reinforce the shift of attention away from economic equality during the neoliberal era.

To identify this phenomenon, let me introduce the concept of topical exclusion. Topical exclusion is a social mechanism that produces ignorance. Importantly, however, it is distinct from the social mechanisms that produce ignorance in the form of false consciousness. Topical exclusion produces ignorance (about $x$ ) by directing attention (at $y$ ). A range of social mechanisms can be at play in topical exclusion, and none of them need to be intentionally implemented; but they all operate by means of directing attention. In contrast, as the notion of false consciousness suggests, there may be other mechanisms that produce ignorance by distorting the content of what one believes, desires, and values. Epistemically or normatively defective propositional attitudes constitute one way to be ignorant about economic inequality. But topical exclusion functions by directing epistemic and normative attention, as it were, prior to the formation of content. One can also be ignorant about economic inequality simply by virtue of not having thought about it at all. In principle, topical exclusion can be investigated in connection with any topic, but its significance as an analytical tool for a political economy of attention requires a topic of general interest, for example, economic inequality. Paying attention to economic inequality is in the interest of everyone

38. For a study of how identity politics functions to divert attention from economic inequality in the US that is congenial to my argument, see Asad Haider, Mistaken Identity: Race and Class in the Age of Trump (New York, 2018).

39. John Rawls, Political Liberalism (New York, 1993), pp. xvii, xxv. See also Rawls, "The Idea of Public Reason Revisited," University of Chicago Law Review 64 (Summer 1997): 807. 
except those individuals and corporations who are benefiting from a given pattern of distribution whose justification would not survive scrutiny.

As it happens, the topic of economic equality has become marginalized concurrently with the shift of political attention to identity politics. I am not suggesting that this development is congenial to Foucault's work, but it is nevertheless one of its unintended effects. In 1982, Foucault crystallized his view of the politically pivotal role of subjectivity by saying that "there is no other point of resistance to political power, from the beginning till the end, than in the relation of the self to itself." ${ }^{\circ}$ The personal was political before neoliberalism, but during the neoliberal period there has been no academic author whose work has come to consolidate a vision of politics around subjectivity more than Foucault. ${ }^{41}$ The irony here is that Foucault's stature in queer culture as "a fucking saint," to borrow David Halperin's accolade, is based on philosophical commitments that undermine support for any mainstream notion of identity politics whose ultimate goal is recognition. ${ }^{42}$ As careful readers of Foucault know, the overarching ambition of "a historical ontology of ourselves" is to question, destabilize, even destroy who one is instead of solidifying the given identities in a pluralistic liberal framework of reciprocal recognition (“Q," p. 1393). On Foucault's view, such "history will be 'effective' to the extent that it makes our very being discontinuous." ${ }^{43}$ Nevertheless, it is the most lasting effect of Foucault's work that we find it commonplace today to think, however superficially or confusedly, that identity constitutes the substance of political struggle and therefore also the fundamental topic of political discourse and imagination. But focusing, if not reducing politics to questions about subjectivity is awfully convenient to those individuals and corporations who economically benefit from the neoliberal governmental rationality that is responsible for the remarkable regress in economic equality since 1980. For them, Foucault's focus on the political stakes of subjectivity has proven an unlikely but nevertheless efficient ally.

40. Foucault, L’Herméneutique du sujet: Cours au Collège de France 1981-1982 (Paris, 2001), p. 241. See Foucault, "Political Spirituality as the Will for Alterity: An Intervierw with the Nouvel Observateur," Critical Inquiry 47 (Autumn 2020): 121-34. For the history of this recently discovered interview, see Sabina Vaccarino Bremner, "Introduction to Michel Foucault's 'Political Spirituality as the Will for Alterity," Critical Inquiry 47 (Autumn 2020): 115-20. While the academic edition of the French original is in preparation, the Nouvel Observateur published the interview in French online, behind a paywall, on 7 February 2018.

41. For an account of the reception of French theory in the US as the new radical theory that marginalized Marxism and other approaches concerned with economic inequality, see François Cusset, French Theory: How Foucault, Derrida, Deleuze, \& Co. Transformed the Intellectual Life of the United States, trans. Jeff Fort (Minneapolis, 2008).

42. Halperin, Saint Foucault, p. 6.

43. Foucault, "Nietzsche, la généalogie, l'histoire," in Dits et écrits, 1:1015. Foucault here elaborates on Nietzsche's notion of effective history (wirkliche Historie). 
Having said that, it is important not to lose sight of the two completely different ways in which the topic of economic justice has been excluded. The neoliberal governmental rationality operates a conceptual erasure of the normative perspective that is needed for such questions to be formulated at all, but no such conceptual reconfiguration can be found in Foucault's work. And, as I have argued, Foucault's overarching project should be appreciated as work that tackles fundamental problems of inequality, even though he never explicitly put it that way. Moreover, it would be false to think that Foucault's analytic of power neglects the economic dimension of social relations. But how exactly the economic dimension relates to relations of power in Foucault's analysis, including its continuities and disagreements with Marx, is a topic in its own right I must postpone to another occasion.

\section{Conclusion}

I hope it is clear now that the relationship between Foucault's work and neoliberalism is more complex than has been appreciated on either side of the controversy. I have tried to show that by doing two things. First, I argued that Foucault's sympathetic discussion of Becker's ideas must be interpreted against the backdrop of Foucault's sustained concern with normalization, which also limits his salutary response to Becker's neoliberalism to the domain of penality. I then explained how Foucault's focus on the political stakes of subjectivity has posthumously come to function as an unwitting ally of neoliberal governmental rationality by reinforcing the topical exclusion of economic equality. Although my analysis here builds upon Foucault's own methodological ideas, it also involves an important divergence because topical exclusion links a strategy of power to ignorance, not knowledge. Therefore, it may seem that the concept of topical exclusion cannot be adopted into the analytical framework Foucault developed for studying how power is exercised. But Foucault's analytic of power involves no commitment to some mechanism of power being essential. When Foucault argues against the view that techniques and effects of power are negative- that power restricts, forbids, represses, says "no"- - his aim is not to deny the existence of such negative mechanisms but to make conceptual room for other, positive, techniques of power. The target of Foucault's criticism is the received view of power as essentially restrictive, a "postulate" he rejects, as follows:

This postulate is that power, especially repressive power, would always and essentially produce effects of miscognition [meconnaissance]. In acting as a ban, in barring access to manifestation, the major effect of repressive power would be to prevent the formation of knowledge: to prevent it in the strongest sense, by producing the unconscious; or 
to prevent it in a weaker and more superficial sense, by bringing about a whole series of effects on the order of denial of reality, ignorance, blindness, or false consciousness.

In brief, the major effect of power would be not knowing, or at any rate the impossibility of access to the truth. Power would be that which bars access to the truth. ${ }^{44}$

Invoking this "postulate ... which supposes that wherever there is power the green grass of knowledge cannot grow," Foucault asks "if it wouldn't be possible to ... say that power, with the discursive practices that bear it and pronounce its effects, is the producer of knowledge." 45 But Foucault only rejects, and only needs to reject, the universal claim that power "always and essentially" functions by preventing knowledge, so there is no reason to deny that ignorance, too, could play a role in tactics and strategies through which power is exercised.

Thus, where I deviate from Foucault, my analysis actually shows how to expand his framework. It would be a nonstarter to ask whether relations of power produce knowledge or ignorance. Any adequate approach must acknowledge both options and identify mechanisms that underwrite explanations of both types of case, respectively. Foucault's argument against the repressive hypothesis was needed to explain how the incitation to discourse can be a mechanism of power and why speaking the truth need not set us free. ${ }^{46}$ But a full picture requires that we supplement Foucault's analyses of power and knowledge with tools to explain how relations of power harness, produce, and maintain ignorance. For instance, consider the mechanisms of "white ignorance" that continue to provide strategic support, as Mills argues, to the deeply entrenched power effects of European colonialism. ${ }^{47}$ Only Foucaultian dogma could limit the good "positivist" spirit of an analytic of power, as Paul Veyne characterized Foucault's insistence on the historical particularity of his every object of study. ${ }^{48}$ Despite this "happy positivism," however, Foucault was Kantian enough to be the first to remind us that "it

44. Foucault, "We Are Not Repressed," in The Event (1975), vol. 1 of Schizo-Culture, ed. Sylvère Lotringer and David Morris (Los Angeles, 2013), pp. 149-50; trans. mod., my emphasis. The original French manuscript of this lecture which Foucault delivered in English has been lost. Meconnaissance was translated as "misrecognition," although Foucault's claim clearly concerns cognition, not recognition.

45. Ibid., p. 150; my emphasis.

46. See Foucault, La volonté de savoir, pp. 25-49.

47. See Charles Mills, "White Ignorance," in Race and Epistemologies of Ignorance, ed. Shannon Sullivan and Nancy Tuana (Albany, N.Y., 2007), pp. 11-38.

48. Paul Veyne, "Foucault Revolutionizes History," in Foucault and His Interlocutors, ed. Davidson (Chicago, 1997), p. 147. 
is not enough to open the eyes, to pay attention . . . for new objects to immediately light up," but any inquiry, including the analysis of relations of power, is shaped by its conceptual resources and theoretical outlook. ${ }^{49}$ Accordingly, I believe that the formidable challenge to make sense of a strategic link between Foucault's work and neoliberal governmental rationality, without conflating it with Foucault's sympathetic engagement with Becker's work in 1979, has been largely due to a lack of adequate conceptual tools. In addition to disentangling those two dimensions of Foucault's relationship with neoliberalism, my analysis illustrates why Foucault's framework for studying relations of power needs to be supplemented with the concept of topical exclusion. The fruitfulness of that concept can be measured by the success of my attempt to provide a more nuanced analysis of Foucault's complex relationship with neoliberalism. 